\title{
PENGARUH PEMBERIAN RANSUM DENGAN BEBERAPA LEVEL SERAT KASAR PADA PERIODE AWAL TERHADAP BOBOT ORGAN FISIOLOGIS AYAM BROILER PASCA PEMBERIAN RANSUM NORMAL
}

\section{Devi Dianti}

\author{
Fakultas Pertanian Universitas Islam Indragiri Hilir Tembilahan Riau \\ *Email: devi_dianti@ymail.com
}

\begin{abstract}
ABSTRAK
Penelitian ini dilakukan untuk mengetahui pengaruh pemberian ransum dengan beberapa level serat kasar pada periode awal terhadap bobot organ fisiologis ayam broiler pasca pemberian ransum normal.

Ternak yang digunakan dalam penelitian ini adalah 80 ekor anak ayam broiler umur 1 hari atau Day Old Chick (DOC) dari strain Cobb. Ransum yang diberikan disusun sendiri dari: jagung, bungkil kedelei, tepung ikan, dedak, ampas sagu, minyak sawit dan top mix. Ransum disusun secara isokalori $(3000 \mathrm{kkal} / \mathrm{kg})$ dan isoprotein (19 \%), kecuali ransum E dimana terjadi penurunan protein kasar akibat peningkatan pemberian serat kasar tinggi. Air minum diberikan secara ad libitum (tidak terbatas).

Penelitian ini menggunakan Rancangan Acak Lengkap (RAL) dengan lima perlakuan pemberian serat kasar dalam ransum yang terdiri dari : A $(6 \% \mathrm{SK})$, B (8\%SK), C $(10 \% \mathrm{SK})$, D $(12 \% \mathrm{SK})$ dan E (14\%SK). Masing-masing perlakuan mendapat 4 ulangan. Perbedaan antara perlakuan diuji dengan uji lanjut DMRT. Peubah yang diamati adalah bobot jantung, bobot hati, bobot ginjal, bobot pankreas, bobot tiroid ayam pada umur 3 minggu dan 8 minggu (mg/100 g bobot hidup).

Hasil pengamatan menunjukkan penggunaan serat kasar sampai level $14 \%$ dalam ransum ayam broiler berpengaruh sangat nyata $(\mathrm{P}<0.01)$ terhadap bobot organ fisiologis. Hal ini terjadi karena pembesaran bobot organ fisiologis akibat meningkatnya kerja organ fisiologis dalam mencerna serat kasar.
\end{abstract}

Kata Kunci : serat kasar, organ fisiologis, ayam broiler

\section{PENDAHULUAN}

Seiring dengan berkembangnya ilmu pengetahuan dan teknologi maka keinginan manusia untuk meningkatkan kesejahteraan hidupnya ditinjau dari segi kesehatan semakin meningkat. Terlihat dari adanya upaya memperbaiki standar gizi nasional dari pihak pemerintah yang menargetkan tercapainya asupan protein 6 gr per kapita per tahun (Ditjen Peternakan, 1990).
Sumber terbesar dari kebutuhan gizi tersebut berasal dari daging. Sesuai dengan keadaan perekonomian saat ini, masyarakat Indonesia cenderung lebih memilih daging ayam ras pedaging atau ayam broiler dibanding daging sapi atau daging ayam bukan ras. Karena disamping harganya lebih murah, produksi dagingnya lebih banyak dan serat dagingnya lebih empuk. Hal tersebut dikarenakan ayam broiler memiliki kemampuan menghasilkan 
daging dalam pemeliharaan yang cukup singkat, yaitu dalam masa pemeliharaan 5 - 6 minggu dapat mencapai bobot tubuh antara 1,4 - 1,6 kg per ekor (Rasyaf, 2002).

Hal di atas tidak terlepas dari peranan kandungan bahan pakan dalam ransum. Untuk meningkatkan efesiensi pakan maka diberikan perlakuan serat kasar tinggi dalam ransum, walaupun terjadi peningkatan bobot organ pencernaan karena organ ini bekerja keras (Brogman ,1975) yang dikutip oleh Silva (2001). Dengan terganggunya daya kerja organ pencernaan maka secara tidak langsung ikut mempengaruhi kerja organ fisiologis. Dimana fungsi organ fisiologis dalam mentransfer zat makanan yang tidak tercerna secara sempurna pada organ pencernaan menyebabkan organ fisiologis harus bekerja lebih ekstra. Hal ini dapat menyebabkan terjadinya hipertropi pada organ fisiologis.

Pemberian ransum berserat kasar tinggi mengakibatkan usus halus menjadi tipis dan panjang, kondisi ini tentu akan menambah waktu pencernaan dan penyerapan. Dari hasil penelitian Febriyenti (2001) pemberian serat kasar sampai level $10 \%$ dalam ransum berpengaruh sangat nyata terhadap ketebalan usus halus dan terjadi penipisan usus halus sebesar $57 \mathrm{mg} / \mathrm{cm}$. Pemberian ransum normal pasca pemberian ransum berserat kasar tinggi diharapkan akan mengakibatkan efesiensi penggunaan ransum. Serat kasar yang digunakan sebagian besar berasal dari ampas sagu (Metroxylon sp).

Pemberian serat kasar sampai dengan $8 \%$ belum menyebabkan perubahan secara nyata pada jantung dan ginjal (Navis, 2001); dan juga pada hati (Akiba and Matsumoto, 1978).

Berdasarkan uraian di atas penulis tertarik untuk melakukan penelitian yang berjudul "Pengaruh Pemberian Ransum dengan beberapa Level Serat Kasar pada Periode Awal terhadap Bobot Organ Fisiologis Ayam Broiler Pasca Pemberian Ransum Normal".

Tujuan penelitian ini adalah untuk mengetahui batas level pengunaan serat kasar yang optimal dikonsumsi oleh ayam broiler. Disamping mengetahui pengaruh terhadap bobot organ fisiologis ayam broiler yang diberikan ransum dengan level serat kasar yang berbeda $(6-14 \%)$, dan bobot organ fisiologis ayam broiler setelah dikembalikan ke ransum normal.

Manfaat dari penelitian ini adalah untuk menambah ilmu pengetahuan Peneliti tentang efek ransum berserat kasar tinggi terhadap organ fisiologis ayam broiler.

Hipotesis penelitian adalah pemberian serat kasar hingga level 14\% dalam ransum ayam broiler, tidak berpengaruh nyata terhadap organ fisiologis ayam broiler.

\section{MATERI DAN METODE PENELITIAN}

\section{Materi Penelitian}

Ternak penelitian. Ternak yang digunakan dalam penelitian ini adalah 80 ekor anak ayam broiler umur 1 hari atau Day Old Chick (DOC) dari strain Cobb.

Kandang penelitian. Kandang dan perlengkapan kandang yang digunakan dalam penelitian ini adalah kandang dengan sistem cage yang masing-masing berukuran $75 \mathrm{~cm} \mathrm{x} 60$ $\mathrm{cm} \times 50 \mathrm{~cm}$ per unitnya, dilengkapi dengan tempat makan dan tempat minum serta lampu pijar 60 watt sebanyak 20 buah sebagai sumber pemanas dan penerangan. Masing-masing unit ditempati oleh 4 ekor ayam. Alat-alat yang digunakan terdiri dari timbangan 
elektrik, timbangan merek $\mathrm{O}$ Haus berkapasitas 2610 gram, pisau, gunting dan lain-lain.

Ransum penelitian. Ransum yang diberikan disusun sendiri dari bahan-bahan seperti : jagung, bungkil kedelei, tepung ikan, dedak, ampas sagu, minyak sawit dan top mix. Ransum disusun secara isokalori (3000 kkal/kg) dan isoprotein (19\%), kecuali ransum
E dimana terjadi penurunan protein kasar akibat peningkatan pemberian serat kasar tinggi. Air minum diberikan secara ad libitum (tidak terbatas).

Kandungan zat-zat makanan dan energi metabolisme bahan penyusun ransum dapat dilihat pada Tabel 1 . Komposisi ransum perlakuan pada Tabel 2.

Tabel 1. Komposisi Zat Makanan dan Energi Metabolisme Bahan Makanan Penyusun Ransum

\begin{tabular}{|l|c|c|c|c|c|c|}
\hline \multirow{2}{*}{ Bahan Makanan } & PK & LK & SK & Ca & P & $\begin{array}{c}\text { ME } \\
\text { (Kkal/kg) }\end{array}$ \\
\cline { 2 - 6 } & \multicolumn{5}{|c|}{$\%$} \\
\hline Jagung & 9.31 & 4.10 & 3.21 & 0.61 & 0.48 & 3370 \\
\hline Bungkil kedelei & 36.98 & 4.17 & 6.73 & 0.60 & 0.48 & 2240 \\
\hline Tepung ikan & 56.00 & 4.43 & 4.75 & 4.42 & 2.31 & 2630 \\
\hline Dedak & 11.24 & 2.45 & 11.48 & 0.64 & 0.44 & 1630 \\
\hline Ampas sagu & 7.89 & 1.52 & 24.58 & 0.17 & 0.06 & 3000 \\
\hline M. sawit & 0 & 100 & 0 & 0 & 0 & 8950 \\
\hline Top mix & 0 & 0 & 0 & 5.38 & 1.14 & 0 \\
\hline
\end{tabular}

Sumber : Sabrina (2002) Seminar Regional SumBar.

Tabel 2. Komposisi Bahan Makanan Penyusun Ransum

\begin{tabular}{|l|r|r|r|r|r|}
\hline \multirow{2}{*}{ Bahan Makanan } & \multicolumn{6}{|c|}{ Perlakuan (\%) } \\
\cline { 2 - 6 } & \multicolumn{1}{|c|}{ A } & \multicolumn{1}{|c|}{ B } & \multicolumn{1}{c|}{ C } & \multicolumn{1}{c|}{ D } & \multicolumn{1}{c|}{ E } \\
\hline Jagung & 55.5 & 48.0 & 39.0 & 29.0 & 20.0 \\
\hline Bungkil kedelei & 12.5 & 13.0 & 13.0 & 13.0 & 12.5 \\
\hline Tepung ikan & 15.0 & 15.0 & 15.0 & 15.0 & 15.0 \\
\hline Dedak & 5.0 & 2.0 & 1.0 & 1.0 & 0.5 \\
\hline Ampas sagu & 10.0 & 20.0 & 30.0 & 40.0 & 50.0 \\
\hline M. sawit & 1.5 & 1.5 & 1.5 & 1.5 & 1.5 \\
\hline Top mix & 0.5 & 0.5 & 0.5 & 0.5 & 0.5 \\
\hline Jumlah & $\mathbf{1 0 0}$ & $\mathbf{1 0 0}$ & $\mathbf{1 0 0}$ & $\mathbf{1 0 0}$ & $\mathbf{1 0 0}$ \\
\hline
\end{tabular}

Ket : disusun dengan cara Trial and Error

Tabel 3. Kandungan Zat-zat Makanan serta Energi Metabolisme

\begin{tabular}{|l|r|r|r|r|r|}
\hline \multirow{2}{*}{$\begin{array}{c}\text { Zat-zat } \\
\text { Makanan }\end{array}$} & \multicolumn{6}{c|}{ Perlakuan (\%) } \\
\cline { 2 - 6 } & \multicolumn{1}{c|}{ A } & \multicolumn{1}{c|}{ B } & \multicolumn{1}{c|}{ D } & \multicolumn{1}{c|}{ E } \\
\hline Protein kasar & 19.54 & 19.48 & 19.32 & 19.18 & 18.89 \\
\hline Lemak kasar & 5.24 & 5.03 & 4.79 & 4.53 & 4.28 \\
\hline Serat kasar & $\mathbf{6 . 3 7}$ & $\mathbf{8 . 2 7}$ & $\mathbf{1 0 . 3 3}$ & $\mathbf{1 2 . 4 7}$ & $\mathbf{1 4 . 5 4}$ \\
\hline Calsium & 1.15 & 1.11 & 1.06 & 1.02 & 0.98 \\
\hline Phospor & 0.71 & 0.67 & 0.62 & 0.58 & 0.54 \\
\hline Energi Metabolis & 3094 & 3098 & 3074 & 3031 & 3003 \\
\hline
\end{tabular}

Ket : disusun berdasarkan tabel 1 dan 2 


\section{Metode Penelitian}

\section{Rancangan dan Model Matematika}

Penelitian ini menggunakan

Rancangan Acak Lengkap (RAL)

dengan lima perlakuan pemberian serat

kasar dalam ransum yang terdiri dari : A

(6\%SK), B (8\%SK), C (10\%SK), D

(12\%SK) dan E (14\%SK). Masing-

masing perlakuan mendapat 4 ulangan.

\section{Peubah yang diukur}

1. Bobot jantung, merupakan hasil penimbangan pada waktu pemotongan ayam pada umur 3 minggu dan 8 minggu $(\mathrm{mg} / 100 \mathrm{~g}$ bobot hidup).

2. Bobot hati, merupakan hasil penimbangan pada waktu pemotongan ayam pada umur 3 minggu dan 8 minggu $(\mathrm{mg} / 100 \mathrm{~g}$ bobot hidup).

3. Bobot ginjal, merupakan hasil penimbangan pada waktu pemotongan ayam pada umur 3 minggu dan 8 minggu $(\mathrm{mg} / 100 \mathrm{~g}$ bobot hidup).

4. Bobot pankreas, merupakan hasil penimbangan pada waktu pemotongan ayam pada umur 3 minggu dan 8 minggu $(\mathrm{mg} / 100 \mathrm{~g}$ bobot hidup).

5. Bobot tiroid, merupakan hasil penimbangan pada waktu pemotongan ayam pada umur 3 minggu dan 8 minggu $(\mathrm{mg} / 100 \mathrm{~g}$ bobot hidup).

\section{Pelaksanaan Penelitian}

1. Persiapan Ransum Penelitian Bahan-bahan penyusun ransum seperti : jagung, bungkil kedelei, tepung ikan, dedak, ampas sagu, minyak sawit dan top mix, masing-masing ditimbang menurut komposisi ransum perlakuan kemudian diaduk sampai merata.

2. Persiapan Kandang

- Satu minggu sebelum DOC masuk, kandang sudah harus dibersihkan dengan pengapuran dan pemberian desinfektan, begitu juga halnya dengan peralatan yang digunakan seperti tempat makan dan tempat minum.

- Lampu pijar 60 watt sebanyak 10 buah, alas kandang, tirai tempat makan dan tempat minum sudah dipasang sebelum anak ayam masuk kandang. Lampu dipasang setiap hari sampai anak ayam berumur 2 minggu selanjutnya lampu hanya dipasang pada malam hari saja sebagai penerangan.

- Pengacakan kandang dilakukan dengan sistem lotre.

3. Persiapan anak ayam dalam kandang

80 ekor anak ayam dimasukkan ke dalam kandang yang telah dilengkapi dengan peralatan kandang dan penerangan satu persatu secara acak.

4. Pemberian ransum dan air minum

- Pemberian ransum terdiri dari tiga tahap yaitu pada umur 1 hari s/d 3 hari digunakan ransum komersil (311). Pada umur 4 hari s/d 3 minggu digunakan ransum 
perlakuan (ransum A, B, C, D dan E). Pada umur 4 minggu s/d 8 minggu digunakan ransum normal (ransum A) dengan kandungan serat kasar $6 \%$ dalam ransum.

- Pemberian ransum dilakukan 2 kali sehari yaitu pagi dan sore hari, sedangkan pemberian air minum diberikan secara ad libitum

- Setiap ransum yang akan diberikan ditimbang sesuai dengan kebutuhan

\section{Proses Pengeluaran Organ}

1. Pemotongan ayam, ayam yang dipotong berdasarkan ayam dengan bobot badan yang mendekati rata-rata.

2. Pencabutan bulu, dilakukan terlebih dahulu perendaman dengan air panas agar bulu ayam mudah dicabut.

3. Pengambilan organ fisiologis (jantung, hati, ginjal, pankreas dan tiroid), menggunakan pisau, pinset dan gunting.

\section{HASIL DAN PEMBAHASAN}

\section{Pengaruh Perlakuan Terhadap Bobot Jantung}

Pada tabel berikut ditampilkan rataan bobot jantung, hati dan ginjal ayam broiler yang diperoleh pada pemotongan I (3 minggu penelitian) dan pada pemotongan II (8 minggu penelitian).

Tabel 5. Rataan Bobot Jantung, Hati dan Ginjal Ayam Broiler pada Pemotongan I (mg/100gr bobot hidup)

\begin{tabular}{|c|c|c|c|}
\hline $\begin{array}{c}\text { Perlakuan Level } \\
\text { Serat Kasar }\end{array}$ & Jantung & Hati & Ginjal \\
\hline A (6\% SK) & $631.56^{\mathrm{A}}$ & $2337.54^{\mathrm{A}}$ & $622.98^{\mathrm{A}}$ \\
$\mathrm{B}(8 \%$ SK) & $703.90^{\mathrm{AB}}$ & $2529.17^{\mathrm{AB}}$ & $706.40^{\mathrm{AB}}$ \\
C (10\% SK) & $768.59^{\mathrm{B}}$ & $2600.11^{\mathrm{AB}}$ & $755.11^{\mathrm{B}}$ \\
D (12\% SK) & $781.69^{\mathrm{B}}$ & $2923.79^{\mathrm{BC}}$ & $775.11^{\mathrm{B}}$ \\
E (14\% SK) & $807.60^{\mathrm{B}}$ & $3210.32^{\mathrm{C}}$ & $802.41^{\mathrm{B}}$ \\
\hline
\end{tabular}

Ket : Superskrip yang berbeda pada kolom yang sama menunjukkan hasil yang berbeda sangat nyata $(\mathrm{P}<0.01)$

Tabel 6. Rataan Bobot Jantung, Hati dan Ginjal Ayam Broiler pada Pemotongan II (mg/100gr bobot hidup)

\begin{tabular}{|c|c|c|c|}
\hline $\begin{array}{c}\text { Perlakuan } \\
\text { (ransum normal) }\end{array}$ & Jantung & Hati & Ginjal \\
\hline A (6\% SK) & $439.93^{\mathrm{A}}$ & $1725.05^{\mathrm{a}}$ & $530.69^{\mathrm{A}}$ \\
$\mathrm{B}(6 \%$ SK) & $480.37^{\mathrm{A}}$ & $1751.55^{\mathrm{ab}}$ & $587.33^{\mathrm{AB}}$ \\
$\mathrm{C}(6 \%$ SK) & $576.00^{\mathrm{B}}$ & $1844.18^{\mathrm{bc}}$ & $602.70^{\mathrm{ABC}}$ \\
D (6\% SK) & $616.67^{\mathrm{B}}$ & $1854.09^{\mathrm{c}}$ & $652.10^{\mathrm{BC}}$ \\
E (6\% SK) & $642.53^{\mathrm{B}}$ & $1881.98^{\mathrm{c}}$ & $677.57^{\mathrm{C}}$ \\
\hline
\end{tabular}

Ket : Superskrip yang berbeda pada kolom yang sama menunjukkan hasil yang berbeda sangat nyata $(\mathrm{P}<0.01)$ 
Analisis

memperlihatkan bahwa penggunaan serat kasar sampai level $14 \%$ dalam ransum memberikan pengaruh berbeda sangat nyata $(\mathrm{P}<0.01)$ terhadap bobot jantung. Hasil uji lanjut DMRT pada pemotongan I menunjukkan perlakuan A tidak berbeda nyata dengan perlakuan B. Hal ini menunjukkan bahwa pemberian serat kasar sampai level $8 \%$ dalam ransum tidak memperlihatkan pengaruh yang nyata terhadap peningkatan bobot jantung. Tetapi perlakuan A berbeda sangat nyata $(\mathrm{P}<0.01)$ dengan perlakuan C, D dan E. Yang berarti terjadinya peningkatan bobot jantung ayam broiler pada level serat kasar $10 \%$ dalam ransum.

Pada akhir penelitian uji DMRT hampir sama dengan pemotongan I, dimana uji menunjukkan perlakuan A tidak berbeda nyata dengan perlakuan B. Tetapi A berbeda sangat nyata $(\mathrm{P}<0.01)$ dengan perlakuan $\mathrm{C}, \mathrm{D}$ dan $\mathrm{E}$.

Berbeda sangat nyata ini disebabkan oleh penggunaan serta kasar tinggi dalam ransum yang mengakibatkan jantung bekerja lebih aktif sehingga jantung mengalami pembesaran dari bobot normal. Ressang (1963) menyatakan bahwa jantung akan mengalami hipertropi apabila terjadi peningkatan aktifitasnya dalam rangka menjaga keseimbangan aliran darah tubuh.

Dari hasil penelitian didapat bobot jantung ayam broiler pada pemotongan I berkisar antara 631.56 $807.60 \mathrm{mg} / 100 \mathrm{gr}$ bobot hidup atau 0.63 - $0.81 \%$ dari bobot hidup, hasil ini sesuai dengan penelitian Yalcin (2003) yang menyatakan bahwa rata-rata bobot jantung ayam broiler umur 21 hari sebesar $0.75 \%$ dari bobot hidup. Sedangkan pada pemotongan II bobot jantung berkisar antara $439.93-642.53$ $\mathrm{mg} / 100 \mathrm{gr}$ bobot hidup atau $0.43-0.64 \%$ dari bobot hidup. Hasil yang didapat setara dengan Koch (1973) yang menyatakan bahwa berat jantung ayam broiler adalah $0.44 \%$ dari bobot hidup.

\section{Pengaruh Perlakuan Terhadap Bobot Hati}

Hati berfungsi mensekresikan asam empedu, metabolisme protein, lemak karbohidrat, besi dan menyimpan vitamin. Pengaruh perlakuan terhadap bobot hati selama penelitian disajikan pada Tabel 5 dan Tabel 6 .

Hasil analisis keragaman menunjukkan bahwa penggunaan serat kasar hingga $14 \%$ dalam ransum memberikan pengaruh berbeda sangat nyata $(\mathrm{P}<0.01)$ terhadap bobot hati. Sedangkan pada akhir penelitian hasil analisis keragaman menunjukkan bahwa penggunaan serat kasar normal $(6 \%)$ dalam ransum berpengaruh berbeda nyata $(\mathrm{P}<0.05)$ terhadap bobot hati. Hal ini sesuai dengan pendapat Tanudimadja (1980) bahwa hati akan membesar jika mendapat cekaman makanan. Cekaman makanan terhadap hati terjadi karena adanya kandungan serat kasar yang tinggi dalam ransum.

Hasil uji DMRT menunjukkan perlakuan A tidak berbeda nyata dengan perlakuan B dan C, tetapi berbeda sangat nyata dengan $D$ dan $E$. Berarti penggunaan serat kasar sampai level $10 \%$ dalam ransum masih dapat ditolerir oleh hati ayam broiler.

Dari hasil penelitian bobot hati berkisar antara $2.3-3.2 \%$ dari bobot hidup pada pemotongan I, bobot tersebut sesuai dengan hasil penelitian Lee (2003) yaitu rata-rata bobot hati ayam broiler umur 3 minggu adalah $2.95 \%$ dari bobot hidup. Pada pemotongan II bobot hati berkisar antara $1.7-1.9 \%$ dari bobot hidup. Hal ini sesuai dengan pendapat Nickel $d k k$ (1977) bahwa bobot 
hati unggas berkisar antara $31-35$ gr atau $1.7-2.3 \%$ dari bobot hidup.

\section{Pengaruh Perlakuan Terhadap Bobot} Ginjal

Ginjal bekerja untuk mempertahankan keadaan yang relatif konstan dari lingkungan internal di dalam tubuh (Franson, 1992).

Hasil analisa keragaman menunjukkan bahwa penggunaan serat kasar sampai level 14\% dalam ransum memberikan pengaruh berbada sangat nyata $(\mathrm{P}<0.01 \%)$ terhadap bobot ginjal ayam broiler penelitian. Dan Uji DMRT yang dilakukan menunjukkan bahwa perlakuan A tidak berbeda nyata dengan perlakuan B tetapi berbeda sangat nyata $(\mathrm{P}<0.01)$ dengan $\mathrm{C}, \mathrm{D}$ dan $\mathrm{E}$. Hal tersebut menunjukkan bahwa serat kasar sampai level $8 \%$ dapat digunakan secara optimal oleh ayam broiler.

Seperti yang diterangkan oleh Tanudimadja (1980) bahwa ginjal dapat membesar jika fungsi hati terganggu, dan ditambahkannya bahwa hasil metabolisme hati yang akan dikeluarkan melalui ginjal bekerja lebih aktif yang mengakibatkan membesarnya ginjal.
Dari hasil penelitian didapat bobot ginjal pada pemotongan I berkisar antara $622.98-802.41 \mathrm{mg} / 100 \mathrm{gr}$ bobot hidup atau $0.62-0.80 \%$ dari bobot hidup, setara dengan yang dinyatakan oleh Lee (2003) dalam penelitiannya bahwa rata-rata bobot ginjal ayam broiler umur 3 minggu sebesar $0.80 \%$ dari bobot hidup. Pada pemotongan II 530.69 - $677.57 \mathrm{mg} / 100 \mathrm{gr}$ bobot hidup atau $0.53-0.68 \%$ dari bobot hidup. Berarti hasil ini lebih kecil dari pernyataan Sturkie (1976) bahwa berat ginjal ayam broiler berkisar antara 1 $2.6 \%$ dari bobot hidup.

\section{Pengaruh Perlakuan Terhadap Bobot Kelenjar Pankreas}

Kelenjar pankreas menghasilkan enzim amilase, tripsin dan lipase, masing-masing mencerna karbohidrat, protein dan lemak. Rataan bobot pankreas dan bobot tiroid ayam broiler yang diperoleh pada pemotongan I (3 minggu penelitian) dan pada pemotongan II (8 minggu penelitian) dapat dilihat pada Tabel 7 dan Tabel 8.

Tabel 7. Rataan Bobot Kelenjar Pankreas dan Kelenjar Tiroid Ayam Broiler pada Pemotongan I (mg/100gr bobot hidup)

\begin{tabular}{|c|c|c|}
\hline $\begin{array}{c}\text { Perlakuan Level } \\
\text { Serat Kasar }\end{array}$ & Pankreas & Tiroid \\
\hline A (6\% SK) & $552.85^{\mathrm{A}}$ & $16.87^{\mathrm{A}}$ \\
$\mathrm{B}(8 \%$ SK) & $560.18^{\mathrm{A}}$ & $17.41^{\mathrm{AB}}$ \\
$\mathrm{C}(10 \%$ SK) & $626.38^{\mathrm{AB}}$ & $17.64^{\mathrm{AB}}$ \\
$\mathrm{D}(12 \%$ SK) & $632.84^{\mathrm{AB}}$ & $18.15^{\mathrm{B}}$ \\
E (14\% SK) & $700.15^{\mathrm{B}}$ & $18.21^{\mathrm{B}}$ \\
\hline
\end{tabular}

Ket : Superskrip yang berbeda pada kolom yang sama menunjukkan hasil yang berbeda sangat nyata $(\mathrm{P}<0.01)$ 
Tabel 8. Rataan Bobot Kelenjar Pankreas dan Kelenjar Tiroid Ayam Broiler pada Pemotongan II (mg/100gr bobot hidup)

\begin{tabular}{|c|c|c|}
\hline $\begin{array}{c}\text { Perlakuan } \\
\text { (ransum normal) }\end{array}$ & Pankreas & Tiroid \\
\hline A (6\% SK) & $194.76^{\mathrm{A}}$ & $12.82^{\mathrm{A}}$ \\
$\mathrm{B}(6 \%$ SK) & $198.90^{\mathrm{A}}$ & $13.94^{\mathrm{AB}}$ \\
$\mathrm{C}(6 \%$ SK) & $201.63^{\mathrm{A}}$ & $14.74^{\mathrm{B}}$ \\
$\mathrm{D}(6 \% \mathrm{SK})$ & $220.18^{\mathrm{B}}$ & $14.86^{\mathrm{B}}$ \\
E (6\% SK) & $228.36^{\mathrm{B}}$ & $15.09^{\mathrm{B}}$ \\
\hline
\end{tabular}

Ket : Superskrip yang berbeda pada kolom yang sama menunjukkan hasil yang berbeda sangat nyata $(\mathrm{P}<0.01)$

Hasil analisis keragaman menunjukkan bahwa penggunaan serat kasar sampai level 14\% dalam ransum memberikan pengaruh berbeda sangat nyata $(\mathrm{P}<0.01)$ terhadap bobot kelenjar pankreas.uji lanjut dengan DMRT menunjukkan bahwa perlakuan A tidak berbeda nyata dengan $\mathrm{B}$ dan $\mathrm{C}$. Hal tersebut menunjukkan bahwa penggunaan serat kasar sampai level $10 \%$ dalam ransum tidak memperlihatkan pengaruh yang nyata terhadap peningkatan bobot pankreas ayam broiler. Tetapi perlakuan A berbeda sangat nyata $(\mathrm{P}<0.01)$ dengan $\mathrm{D}$ dan E.

Hal ini sesuai dengan pendapat Vohra dan Kratzer (1964) bahwa ayam yang mendapat makanan yang berserat kasar tinggi ditemukan pembesaran kelenjar pankreas. Girindra (1979) menyatakan bahwa keadaan kualitas ransum rendah, mengakibatkan aktivitas enzim proteolitik meningkat. Cekaman makanan yang disebabkan oleh kualitas ransum yang rendah tersebut menyebabkan hipertropi pankreas.

Dari hasil penelitian bobot pankreas berkisar antara $0.55-0.70 \%$ dari bobot hidup pada pemotongan I, hasil ini lebih besar dibanding dengan hasil penelitian Lee (2003) yaitu $0.37 \%$ dari bobot hidup. Sedangkan pada pemotongan ke II bobot pankreas berkisar antara $0.19-0.23 \%$ dari bobot hidup, hasil ini sesuai dengan yang diterangkan Jull (1979) bahwa bobot pankreas adalah 2.5 - 4 gr dengan bobot hidup 2000 gr atau $0.13-0.2 \%$ dari bobot hidup.

Pengaruh Perlakuan Terhadap Bobot Kelenjar Tiroid

Kelenjar tiroid sangat esensial bagi makhluk hidup karena menghasilkan hormon tiroksin, salah satu fungsinya adalah mempengaruhi metabolisme zat-zat makanan termasuk mineral dan air. Pengaruh perlakuan terhadap bobot kelenjar tiroid disajikan pada Tabel 7 dan Tabel 8.

Analisis keragaman memperlihatkan bahwa penggunaan serat kasar dalam ransum memberikan pengaruh berbeda sangat nyata $(\mathrm{P}<0.01)$ terhadap bobot kelenjer tiroid. Setelah dilakukan uji DMRT didapat perlakuan A tidak berbeda nyata dengan $\mathrm{B}$ dan $\mathrm{C}$, dan berbeda sangat nyata $(\mathrm{P}<0.01)$ dengan $\mathrm{D}$ dan $\mathrm{E}$ sedangkan perlakuan $\mathrm{B}$ tidak berbeda nyata dengan C, D dan E.

Hal ini sejalan dengan peningkatan penggunaan ampas sagu, sehingga meningkat pula jumlah serat kasar dalam ransum. Sesuai dengan pendapat Sturkie (2000) bahwa kandungan serat kasar dalam ransum 
akan meningkatkan kerja kelenjer tiroid untuk mensekresikan hormon tiroksin.

Dari hasil penelitian bobot kelenjer tiroid berkisar antara 16.87 $18.21 \mathrm{mg} / 100$ gr bobot hidup pada pemotongan I. Sedangkan pada pemotongan II didapat bobot kelenjar tiroid 12.82 - $15.09 \mathrm{mg} / 100 \mathrm{gr}$ bobot hidup. Menurut pendapat Ringer (1976) bahwa bobot kelenjer tiroid ayam sekitar 6.3 - $10.7 \mathrm{mg} / 100 \mathrm{gr}$ bobot hidup. Berarti bobot kelenjar tiroid hasil penelitian lebih besar dari hasil penelitian terdahulu.

\section{KESIMPULAN}

Berdasarkan hasil penelitian yang telah dilakukan dapat disimpulkan bahwa penggunaan serat kasar sampai level 14\% dalam ransum ayam broiler berpengaruh sangat nyata $(\mathrm{P}<0.01)$ terhadap bobot organ fisiologis. Hal ini terjadi karena pembesaran bobot organ fisiologis akibat meningkatnya kerja organ fisiologis dalam mencerna serat kasar.

\section{DAFTAR PUSTAKA}

Akiba, M. And T. Matsumoto. 1978. Effect of force feeding dietary cellulose on liver lipid accumulation and lipid composition of liver and plasma in growing chick. J. Nutrition, $108 ; 738-748$.

Ditjen Peternakan. 1990. Peternakan Indonesia Menjelang Era Tinggal Landas dalam Setengah Abad Ayam Ras di Indonesia.

Febriyenti. 2001. Pemberian ampas sagu yang difermentasi dengan Rhizopus sp terhadap organ pencernaan ayam broiler. Skripsi.
Fakultas Peternakan. UNAND. Padang.

Flach, M. 1977. The sago palm and it's yield potensial proceding of laying hens. Journal Poultry Sci. $41: 353-359$.

Koch, T. 1973. Anatomy of The Chicken and Domestic Birds. $1^{\text {st }}$ ed. The Iowa State University Press. Iowa.

Jull, M.A. 1979. Poultry Husbandry. $5^{\text {rd }}$ Ed. Mc Graw Hill Publishing Company LTD. New York.

Lee, J. T., C. A. Bailey, A. L. Cartwright. 2003. Guar meal germ and hull fractions differently affect growth performance and intestinal viscosity of broiler. Poultry science. 82:1589-1595.

Navis, F. 2001. Pengaruh panggunaan bungkil inti sawit yang difermentasi dengan Rhizopus oligoporus dalam ransum terhadap organ fisiologis ayam broiler. Skripsi. Fakultas Peternakan. UNAND. Padang.

Nickle, R. A. Schummer and E. Seiferly. 1977. Anatomy of Domestic Bird. Spinger Ver log. New York. Heidelberg. Berlin.

Rasyaf, M. 2002. Beternak Ayam Pedaging. Penebar Swadaya. Jakarta.

Ressang, A. A. 1984. Patologi Khusus Veteriner, Edisi Ke-2. Direktorat Pembinaan dan Pengabdian Masyarakat. Dirjen Pendidikan Tinggi. Depdikbud Jakarta. Bekerjasama Dengan Balai 
Penelitian Penyakit Hewan. Wilayah IV. Denpasar.

Ringer, R. K. 1976. Thyroid In Avian Physiology. $3^{\text {rd }}$ Ed., Sturkie, P. D. Ed. Springer Verlag. New York. Heidelberg. Berlin.

Sabrina, 2002. Biokonversi campuran ampas sagu dan ampas tahu dan pemanfaatannya sebagai pakan ternak. Seminar Regional Sumatera Barat.

Scott, M.L., M.C. Nesheim and R.J. Young. 1982. Nutrition of The Chicken. M.L. Scott and Association. Ithaca, New York.

Silva, W. 2001. Pengaruh pemberian ampas sagu yang difermentasikan dengan Rhizopus oligoporus terhadap organ fisiologis ayam broiler. Skripsi. Fakultas Peternakan UNAND. Padang.
Steel, R.D.G. and J.H. Torrie. 1980. Prinsip dan Prosedur Statistik Suatu Pendekatan Biometrik. Gramedia. Jakarta.

Sturkie, P.D.. 1976. Avian Physiology. $3^{\text {rd }}$. Ed. Sprienger Verlag, New York.

Tanudimadja. 1980. Anatomi Veteriner IV. Anatomi dan Fisiologi Ayam, Bagian Anatomi Veteriner. Fakultas Kedokteran Hewan IPB. Bogor.

Wahju, J. 1997. Ilmu Nutrisi Unggas.

Gajah Mada University Press.

Yogyakarta.

Yalcin, S., P. B. Siegel. 2003 Exposure to cold or heat during incubation on developmental stability of broiler embryos. Poultry sience. 82:1388-1392. 